\title{
Persepsi Nelayan terhadap Larangan Penggunaan Alat Tangkap Dogol di Kelurahan Manggar Baru Kecamatan Balikpapan Timur
}

\author{
[Perfection Of Fishermen Against The Ban On The Use Of Fishing Gear (Trawl) In The \\ Manggar Baru Village Eastern Subdistrict] \\ Lilis Tiani $^{\bowtie}$, Elly Purnamasari, Said Abdusysyahid \\ Program Studi Agrbisnis Agrobisnis Peikanan, Jurusan Sosial Ekonomi Perikanan \\ Fakultas Perikanan dan Ilmu Kelautan Universitas Mulawarman \\ Jl. Gunung Tabur No. 1 Kampus Gunung Kelua Samarinda \\ Diterima : 10 Oktober 2017; Disetujui : 9 Desember 2017
}

\begin{abstract}
Abstrak
Tujuan dari penelitian ini adalah untuk mengetahui persepsi dan sikap terhadap larangan penggunaan alat menangkap nelaya Dogol (Trawl Hela). Penelitian ini dilakukan selama lima bulan mulai bulan Desember 2016 sampai Juni 2017 di Kabupaten Manggar New Sub Balikpapan Timur. Sampel yang diambil berdasarkan metode proportional random sampling Proportionate ditentukan oleh rumus slovin. Hasil analisis menunjukkan bahwa persepsi nelayan terhadap peraturan menteri tentang larangan penggunaan alat tangkap Dogol (Trawl Hela) dan indikator pengetahuan menempati kategori tinggi (skor 424), indikator kesadaran akan kategori tersebut adalah ( skor 327) dan ketertarikan pada indikator kategori rendah (skor 264) dan sikap nelayan mengambil tindakan terhadap peraturan yang melarang penggunaan alat tangkap nelayan Dogol tidak mau beralih ke alat seperti penangkapan lainnya Trammel net Perikanan, Jaring Gill, rawai dan Departemen Kelautan akan menyarankan pengganti alat penangkapan Dogol. Hal ini karena nelayan menganggap alat pengganti alat tangkap ini dianggap sebagai alat tangkapan musiman sehingga membawa hasil jauh lebih bermanfaat untuk menggunakan alat tangkap Dogol.
\end{abstract}

Kata kunci: persepsi, nelayan, dogol, regulasi.

\begin{abstract}
The purpose of this research is to know the perceptions of and attitudes towards the prohibition of the use of the nelaya capture tool Dogol (Trawl Hela). This research was conducted for five months starting in December 2016 until June 2017 in district Manggar New Sub Balikpapan Timur. Sample taken based on a Proportionate Stratified random sampling method is specified by the formula slovin. The results of the analysis showed that perceptions of fishermen against the ministerial regulation on the prohibition of usage of capture tool Dogol (Trawl Hela) and indicators of knowledge occupies a high category (score 424), an indicator of the awareness in the category are (score 327) and the said interest on the category indicator is low (score 264) and the attitude of fishermen taking action against regulations banning the use of the capture tool Dogol fishermen were not willing to switch to the tool like other capture Trammel net Fishing, Gill nets, rawai and the Marine Department would advise in lieu of Dogol capture tool. This is because the fishermen consider the capture tool replacement is considered a seasonal capture tool then bring results is far more beneficial to use capture tool Dogol.
\end{abstract}

Keywords : perception, fisherman, dogol, regulation.

\footnotetext{
$\triangle$ Penulis Korespondensi :

Alamat Surel : lilistiani69@yahoo.com
} 


\section{PENDAHULUAN}

Indonesia merupakan negara kepulauan terbesar yang dikelilingi lautan yang sangat luas, pulau-pulau yang terbentang dari sabang sampai marauke memiliki sumberdaya perikanan yang sangat kaya dengan hasil perikanan tangkapnya dengan keanekaragaman hayati. Dalam rangka untuk mewujudkan perikanan tangkap yang berkelanjutan, maka eksploitasi sumberdaya hayati laut harus dapat dilakukan secara bertanggung jawab. Untuk menjaga kelestarian sumberdaya ikan perlu adanya pemahaman mengenai penggunaan alat-alat penangkapan ikan yang ramah lingkungan dari segi sifat alat, pengoperasian, daerah penangkapan dan sebagainya.

Kementerian Kelautan dan Perikanan menerbitkan larangan penggunaan alat tangkap pukat hela (trawls) dan pukat tarik (seine nets) di wilayah pengelolaan perikanan Negara Republik Indonesia. Langkah ini dilakukan untuk menjaga kelestarian sumberdaya perikanan khususnya daerah pesisir di Indonesia. Dasar pelarangan penggunaan alat tangkap tersebut didasari oleh semakin menurun dan rusaknya kelestarian sumberdaya ikan.
Kota Balikpapan dari luas wilayah $503,30 \mathrm{Km}^{2}$, memiliki potensi perikanan tangkap seluas $337,805 \mathrm{Km}^{2}$ yang terbentang sepanjang Selat Makassar dan Teluk Balikpapan dan garis pantai sepanjang 45,6 Km. Dengan potensi produksi sumberdaya ikan untuk perairan laut sebesar 16.850 ton/tahun. Dengan potensi laut yang sangat besar di Balikpapan terutama di daerah Kelurahan Manggar Baru banyak warga yang sebagian hidupnya menjadi nelayan tangkap. (Balikpapan dalam Angka, 2015).

Peraturan mengenai pelarangan penggunaan dua alat tangkap ini mengalami pro-kontra di masyarakat. Sebagian masyarakat yang pro menganggap peraturan tersebut akan berdampak baik bagi kelestarian biota laut pada masa akan datang. Sedangkan masyarakat yang tidak setuju yang pada umumnya berprofesi sebagai nelayan menganggap peraturan ini akan berdampak pada hasil tangkapan mereka. Pro-kontra terhadap penerbitan peraturan ini juga terjadi di kalangan nelayan di Kota Balikpapan dimana masyarakat di Kota Balikpapan secara turun temurun menggunakan alat tangkap Pukat hela atau dikenal oleh masyarakat lokal dengan nama alat 
tangkap Dogol, yakni \pm 30 tahun. Awalnya alat tangkap Dogol hanya boleh digunakan oleh kapal berkapasitas kurang dari 5 gross tonnage (GT) .

Manggar Baru adalah satu diantara kelurahan di Kecamatan Balikpapan Timur Kota Balikpapan. Nelayan Kelurahan Manggar Baru sebagian besar menggunakan alat tangkap Dogol (Pukat Hela). Walaupun diketahui bahwa jenis alat tangkap Dogol (Pukat Hela) tidak ramah lingkungan, karena metode pengoprasiannya yang dapat menangkap semua biota laut, dan apabila secara terus menerus maka dapat merusak ekosistem. Problematika yang ada adalah penolakan nelayan Kelurahan Manggar Baru dengan diterbitkannya Peraturan Menteri Kelautan dan Perikanan Republik Indonesia Nomor 2/PERMEN-KP/2015 oleh karena itu perlu adanya penelitian mengenai persepsi nelayan tentang larangan penggunaan alat penangkapan ikan Pukat hela (Trawls) dan Pukat tarik (seine nets).

\section{METODE PENELITIAN}

Penelitian ini dilaksanakan di Kelurahan Manggar Baru Kecamatan Balikpapan Timur Kota Balikpapan. Lama penelitian dilakukan mulai dari
Desember - Mei 2017. Penelitian dilakukan dengan observasi di lokasi penelitian dan melakukan wawancara secara langsung dengan responden yaitu masyarakat nelayan Dogol dengan menggunakan daftar pertanyaan (kuesioner) yang disusun secara dengan tujuan penelitian. Pengambilan sampel dilakukan dengan metode "Proportionate Stratified random sampling”. Responden sabagai sampel yang diambil dalam penelitian ini adalah 35 masyarakat nelayan Dogol.

Penelitian ini dilaksanakan dengan mengintregrasikan pendekatan kualitatif dan kuantitatif. Pendekatan kualitatif bertujuan mengetahui sikap nelayan terhadap kebijakan pemerintah sedangkan pendekatan kuantitatif bertujuan mengetahui persepsi nelayan terhadap larangan penggunaan alat tangkap Dogol (Pukat Hela).

Deskriptif kualitatif bertujuan untuk mengetahui gambaran sikap nelayan Dogol (Pukat Hela) dan permasalahan nelayan terhadap peraturan mengenai pelarangan alat tangkap Dogol dimana deskriptif kualitatif mengungkapkan kejadian atau fakta, keadaan, fenomena, variabel dan keadaan yang terjadi saat penelitian berlangsung dengan menyuguhkan apa yang sebenarnya terjadi. 
Persepsi nelayan terhadap larangan penggunaan alat tangkap Dogol (Pukat Hela) di ukur dengan 3 indikator menggunakan model skala Likert. Model skala Likert adalah bentuk kuisioner yang mengungkap sikap dari responden dalam bentuk jawaban (pertanyaan) yang setiap jawaban tersebut memiliki skor tersendiri sesuai dengan positif atau negatifnya item itu (Subana dan Sudrajat, 2001). Skor berkisar 3-1, jawaban a diberi skor 3, jawaban b diberi skor 2, dan jawaban c diberi skor 1. Kategori yang di gunakan dalam penelitian ini ada 3 yaitu kategori tinggi, sedang dan rendah.

Apabila jumlah kategori yang ditentukan sebanyak tiga kelas yaitu persepsi tinggi, sedang dan rendah, maka menurut Suparman (1990), interval kelas ditentukan sebagai berikut:

$$
\mathrm{C}=\frac{\mathrm{Xn}-\mathrm{Xi}}{\mathrm{K}}
$$

Dimana:

$$
\begin{array}{ll}
\mathrm{C} & =\text { interval kelas } \\
\mathrm{K} & =\text { jumlah kelas } \\
\mathrm{Xn} & =\text { skor maksimum } \\
\mathrm{Xi} & =\text { skor minimum }
\end{array}
$$

\section{HASIL DAN PEMBAHASAN}

\section{Karakteristik Responden}

Karakteristik Nelayan. Karakteristik responden yang dibahas dalam penelitian ini meliputi karakteristik persepsi masyarakat nelayan Kelurahan Manggar Baru terkait dengan diterbitkannya kebijakan pemerintah terhadap pelarangan penggunaan alat tangkap Dogol (Pukat Hela).

\section{Karakteristik Umur Responden.} Suratiyah (2009) mengemukakan seseorang yang telah berumur 15 tahun ke atas baru disebut sebagai nelayan, dibawah umur tersebut walaupun ia melaut tidak disebut sebagai nelayan. Umur juga mempunyai pengaruh terhadap pendapatan walaupun pengaruhnya tidak terlalu besar. Umur seseorang menentukan prestasi kerja atau kinerja orang tersebut. Semakin berat pekerjaan secara fisik, maka semakin tua tenaga kerja akan semakin turun pula prestasinya. Namun, dalam hal tanggung jawab semakin tua umur tenaga kerja tidak akan berpengaruh karena justru semakin berpengalaman.

Keadaan umur responden dapat dilihat pada Tabel 1. 
Tabel 1. Klasifikasi responden berdasarkan tingkat umur

\begin{tabular}{llll}
\hline No & Kelompok Umur (Tahun) & Jumlah (orang) & Presentase \% \\
\hline 1 & $25-45$ & 22 & 62,85 \\
2 & $46-60$ & 10 & 28,57 \\
3 & 61 keatas & 3 & 8,57 \\
\hline & Jumlah & $\mathbf{3 5}$ & $\mathbf{1 0 0 \%}$ \\
\hline
\end{tabular}

berada di Kelurahan Manggar Baru

\section{Karakteristik Responden Ber-} dasarkan Tingkat Pendidikan.

Hasil penelitian terhadap 35 responden menujukkan bahwa kategori pendidikan yang paling dominan adalah yang memiliki tingkat pendidikan sekolah dasar (SD) berjumlah 12 orang atau $20 \%$. Sedangkan kategori yang paling rendah tingkat pendidikan Sekolah Menengah Atas (SMA) dengan banyaknya responden adalah 6 orang atau $17,14 \%$. Hal tersebut dapat dilihat pada Tabel 2.

\section{Karakteristik Responden Ber-} dasarkan Suku. Berdasarkan hasil wawancara dengan responden yang
Kecamatan Balikpapan Timur Kota Balik-papan, Responden sebagian besar adalah berasal dari Sulawesi dan Kalimantan. Responden sebagian besar suku Bugis yakni sebanyak 28 orang sedangkan sisanya bersuku Banjar yaitu 7 orang. Untuk lebih jelasnya dapat dilihat pada Tabel 3.

\section{Karakteristik Responden Ber-} dasarkan Pengalaman Kerja. Nelayan yang ada di Kelurahan Manggar Baru yang dijadikan responden rata-rata memiliki pengalaman kerja 10-20 tahun yaitu sebanyak $62,85 \%$, sedangkan yang memiliki pengalaman kerja 25-30 tahun yaitu sebanyak 28,57\% dan Tabel 2. Karakteristik Responden berdasarkan Pendidikan

\begin{tabular}{llll}
\hline No & Tingkat Pendidiikan & Jumlah (jiwa) & Presentase \\
\hline 1 & Tidak Lulus & 10 & 28,57 \\
2 & Sekolah Dasar & 12 & 34,28 \\
& & & 20 \\
4 & SMP & 7 & 17,14 \\
\hline & SMA & 6 & $\mathbf{1 0 0 \%}$
\end{tabular}


yang memiliki pengalaman kerja 40-

50 tahun yaitu $8,57 \%$ responden.

Jumlah responden berdasarkan pengalaman kerja dapat dilihat pada Tabel 4.

\section{Persepsi Nelayan Manggar Terhadap Larangan Penggunaan Alat Tangkap Dogol (Pukat Hela)}

Berdasarkan hasil wawancara dengan para responden di lokasi penelitian, persepsi masyarakat yang berkaitan dengan PERMEN KP No.2 tahun 2015 tentang larangan penggunaan alat tangkap Dogol (Pukat Hela) di Kelurahan Manggar Baru ditunjukkan pada Gambar 4, 5, dan 6.

Pengetahuan. Pengetahuan nelayan Manggar Baru mengenai peraturan yang melarang alat tangkap yang mereka gunakan saat ini, hal tersebut dapat dibuktikan dalam hasil perhitungan yang didapatkan dari wawancara langsung kepada nelayan di Manggar Baru dan hasilnya bisa dilihat dari Gambar 4.
Hasil dari wawancara kepada responden mengenai pengetahuan nelayan terhadap larangan penggunaan alat tangkap Dogol (Pukat hela) yang terdapat pada Peraturan Menteri No.2 Tahun 2015 menduduki kategori tinggi dengan nilai rata-rata 424 yang berarti bahwa nelayan telah mengetahui pelarangan alat tangkap yang digunakan mereka sehari-harinya untuk mencari nafkah dimana di Kelurahan Manggar Baru sendiri sudah sering kali dilakukan sosialisasi tentang pelarangan alat tangkap yang mereka gunakan ini bahkan ada sebagian nelayan yang mulai sadar akan dampaknya apabila alat tangkap ini terus digunakan tetapi kembali lagi dengan kebutuhan ekonomi para nelayan di Kelurahan Manggar Baru dimana mereka yang sebagian besar bergantungkan hidupnya dengan menggunakan alat tangkap Dogol (Pukat Hela).

Tabel 3. Karakteristik Responden Berdasarkan Suku

\begin{tabular}{cccccc}
\hline No & Suku & $\begin{array}{c}\text { Laki-Laki } \\
\text { (orang) }\end{array}$ & $\begin{array}{c}\text { Perempuan } \\
\text { (orang) }\end{array}$ & Jumlah & $\begin{array}{c}\text { Presentase } \\
\text { (\%) }\end{array}$ \\
\hline 1 & Bugis & 28 & - & 28 & 80 \\
2 & Banjar & 7 & - & 7 & 20 \\
\hline & Jumlah & & & $\mathbf{3 5}$ & $\mathbf{1 0 0}$ \\
\hline
\end{tabular}


Gambar 4. Histogram Indikator Pengetahuan Nelayan terhadap Larangan Penggunaan Alat tangkap dogol (Pukat Hela)

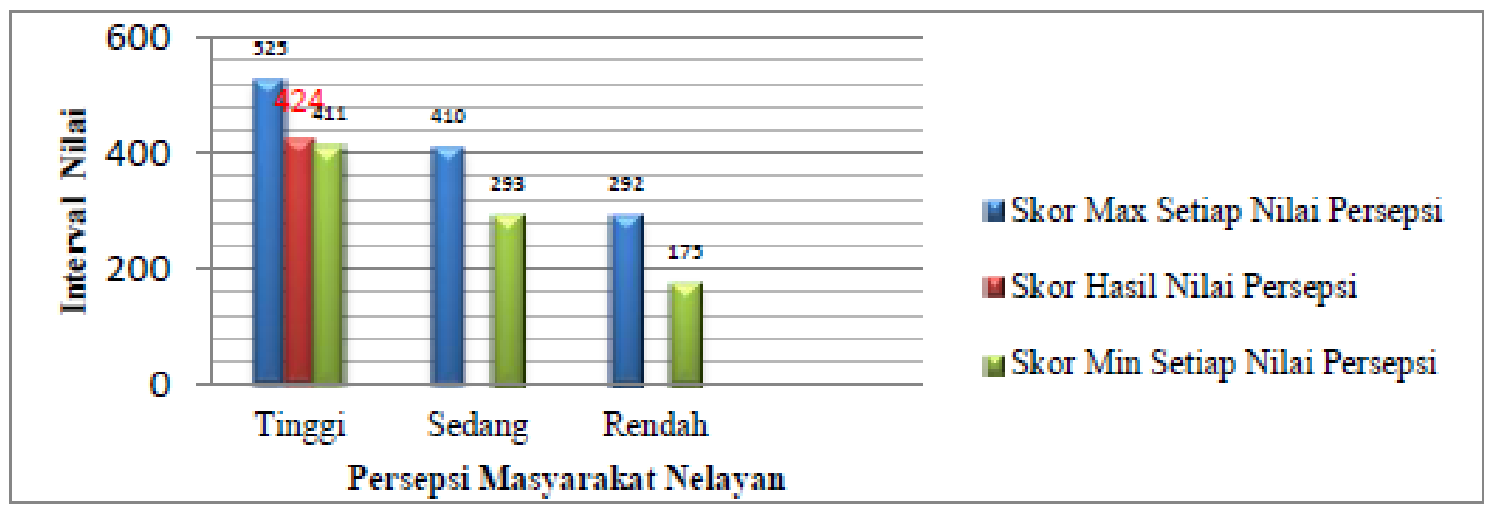

Kesadaran. Kesadaran yang di- dimana sebagian nelayan sadar akan maksud sejauh mana kesadaran nelayan dampak kerusakan biota laut apabila Manggar Baru terhadap peraturan yang melarang alat tangkap yang mereka gunakan saat ini, hal tersebut dapat dibuktikan dalam hasil perhitungan yang didapatkan dari wawancara langsung kepada nelayan di Manggar Baru dan hasilnya bisa dilihat dari grafik di bawah ini.

Hasil dari wawancara yang diperoleh dari para responden dilapangan tingkat kesadaran nelayan terhadap larangan penggunaan alat tangkap Dogol (Pukat hela) menduduki kategori sedang dengan nilai rata-rata 327 terus menerus menggunakan alat tangkap Dogol ini dan juga ada sebagian nelayan yang bahkan tidak merasa adanya dampak buruk yang mereka lakukan selama menjadi nelayan Dogol di Kelurahan Manggar baru ini. Di Kelurahan Manggar Baru sudah sering dilakukan sosialisasi tentang larangan alat tangkap ini tetapi tidak semua paham dengan apa yang dimaksud dari dasar pelarangan penggunaan alat tangkap Dogol ini ada sebagian nelayan yang merasa bahwa mereka tidak merusak biota yang ada dilaut dan ada

Gambar 5. Histogram Indikator Kesadaran Nelayan terhadap Larangan Penggunaan Alat Tangkap Dogol

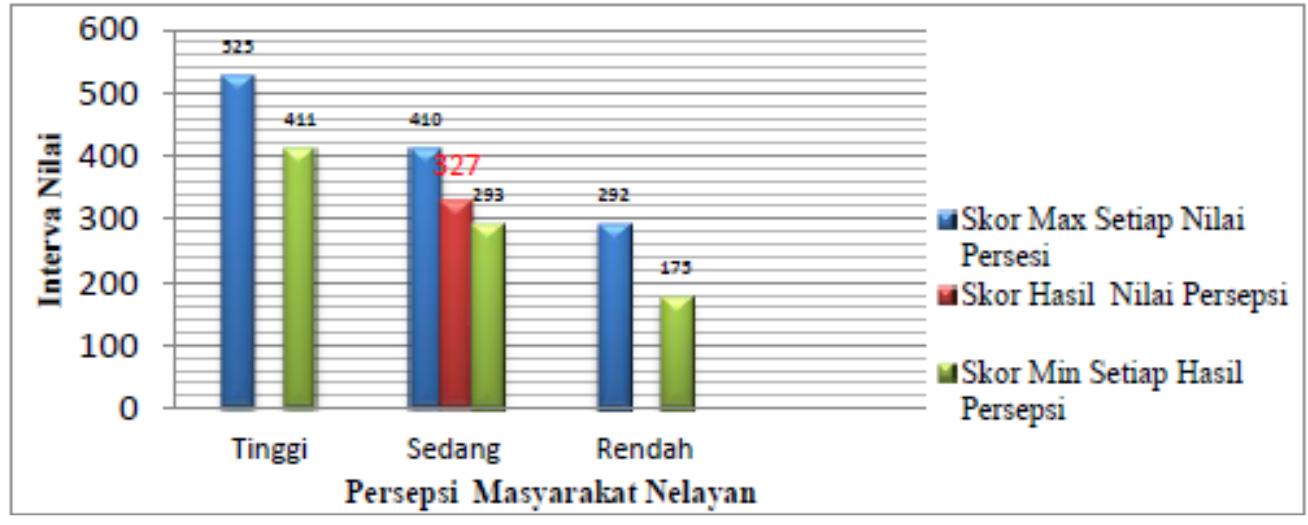


sebagian nelayan dogol yang merasa akan dampak yang dialami seperti over fishing dimana lokasi penangkapan yang mereka tempuh sekarang sudah mulai jauh dari area biasanya dan juga kesadaran dari nelayan ini dipengaruhi oleh tingkat pendidikan yang mereka duduki yang dominan hanya lulusan Sekolah Dasar (SD) dimana tingkat pendidikan yang masih rendah juga sangat mempengaruhi pola fikir nelayan.

Minat. Minat yang dimaksudkan yaitu mengetahui tingkat minat nelayan di Kelurahan Manggar Baru terhadap peraturan menteri No.2 Tahun 2015 mengenai membantu program pemerintah terkait pergantian alat tangkap Dogol menjadi alat tangkap yang ramah lingkungan. Hal tersebut dapat dibuktikan dalam hasil perhitungan yang didapatkan dari wawancara langsung kepada nelayan di Manggar Baru dan hasilnya bisa dilihat pada Gambar 6.
Hasil dari wawancara kepada responden mengenai minat di Kelurahan Manggar Baru terhadap Peraturan Menteri No.2 Tahun 2015 dalam membantu program pemerintah terkait pergantian alat tangkap Dogol (Pukat Hela) menjadi alat tangkap yang ramah lingkungan menduduki kategori rendah dengan nilai rata-rata 264 dimana sebagian besar nelayan menganggap bahwa peraturan tentang larangan penggunaan alat tangkap Dogol (Pukat hela) akan menghentikan pekerjaan mereka dan tentunya mengancam perekonomian warga yang selama ini menggantungkan hidupnya melalui usaha penangkapan ikan dengan alat tangkap Dogol (Pukat Hela).

Tidak hanya para nelayan warga terdampak lainnya adalah pengusaha yang membuat alat tangkap Dogol dan para ibu-ibu pemilah ikan, para tengkulak dan secara luas akan mempengaruhi perekonomian warga Kelurahan

Gambar 6. Histogram Indikator Minat Nelayan terhadap larangan penggunaan Alat Tangkap Dogol

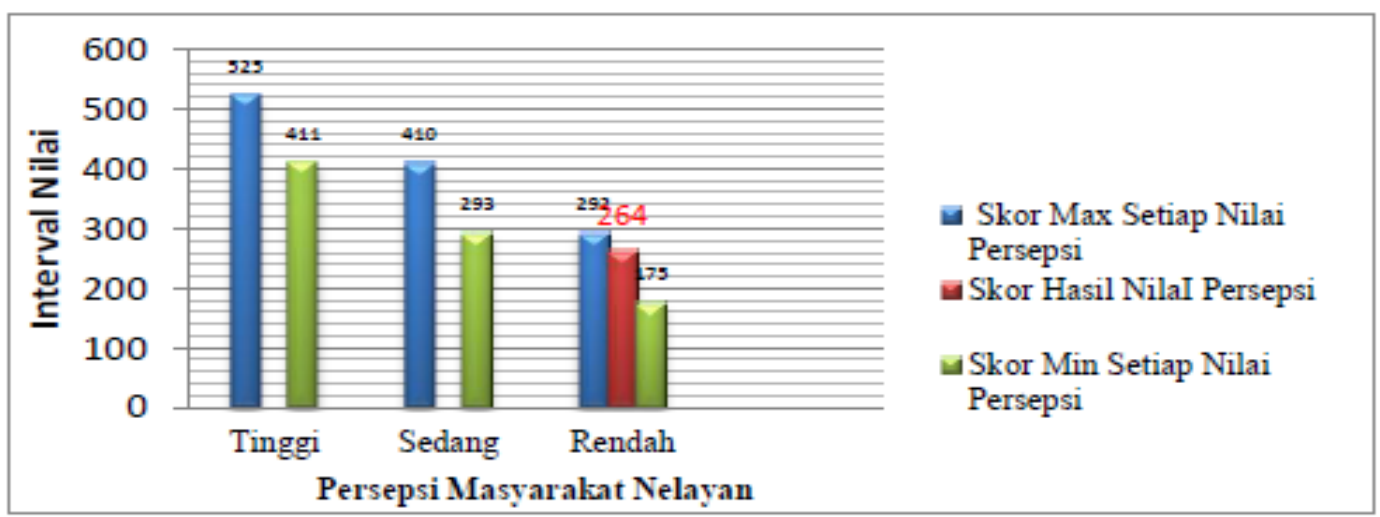


Manggar Baru yang akar perekonomiannya adalah sektor perikanan.

\section{Sikap Nelayan Terhadap Permen KP No 2/2015}

Peraturan ini bukan menjadi hal baru di kalangan masyarakat nelayan yang berada di Kelurahan Manggar Baru peraturan mengenai pelarangan alat tangkap Dogol (Pukat Hela) sudah masuk sejak pada tahun 2015 lalu untuk itu berbagai pihak seperti Dinas Kelautan Dan Perikanan Kota Balikpapan juga sudah mengupayakan bagaimana menghadapi problematika yang sampai saat ini belum terpecahkan pada dasarnya peraturan menteri yang melarang penggunaan alat tangkap Dogol (Pukat Hela) ini kenyataannya sangat kontra dengan nelayan yang berada di Kelurahan Manggar Baru dimana alat tangkap Dogol (Pukat Hela) yang mereka gunakan ini sudah menjadi tradisi nenek moyang nelayan Manggar Baru menggunakan alat tangkap ini sudah sejak dulu untuk itu tidak mudah menggantikan alat tangkap Dogol(Pukat Hela) dengan alat tangkap lainnya. Sehubung dengan hal tersebut strategi yang dilakukan oleh pihak Dinas Kelautan dan Perikanan Kota Balikpapan yaitu memberi bantuan alternatif oleh dari itu penulis akan memaparkan alat tangkap apa saja yang menjadi alternatif yang sudah diupayakan oleh Dinas Kelautan Dan Perikanan Kota Balikpapan.

1) Alternatif Alat Tangkap dari Dinas Kelautan dan Perikanan Kota Balikpapan.

a) Rengge gondrong (Tramel Net) alat ini disarankan oleh pihak Dinas Kelautan dan perikanan kota Balikpapan untuk menggantikan alat tangkap Dogol (Pukat Hela). Konstruksi dan desain Trammel net sangat sederhana sehingga mudah dibuat sendiri oleh nelayan.

b) Gill Net dan Pancing Rawai dimana dinas perikanan kota Balikpapan sudah menurunkan bantuan berupa alat tangkap alternatif. Namun kembali lagi masyarakat nelayan Manggar Baru belum bisa berpaling dari alat tangkap Dogol tentu upaya pengalihan alat tangkap ini dirasa belum berhasil karena nelayan Manggar Baru merasa bahwa alat tangkap yang disarankan itu belum sesuai dengan kreteria yang mereka inginkan alat alternatif tersebut 
dianggap sebagai alat tangkap musiman.

2) Sikap Nelayan Terhadap Permen KP

Berdasarkan wawancara di lapangan sikap nelayan dalam menghadapi problematika yang ada saat ini yaitu nelayan belum bisa mengambil langkah yang tepat mereka tetap bertahan untuk menggunakan alat tangkap Dogol (Pukat Hela) ini dimana menurut nelayan di Kelurahan Manggar Baru hanya alat tangkap ini yang mereka anggap paling efektif. Apabila peraturan ini terpaksa harus me-larang penggunaan alat tangkap ini meraka tetap ingin menjadi nelayan karna menurut nelayan yang ada di Kelurahan Manggar Baru di jaman sekarang sangat susah mencari pekerjaan dengan minimnya pendidikan yang mereka miliki dan hanya sebagai nelayanlah keahlian yang mereka andalkan untuk saat ini.

\section{SIMPULAN}

1. Persepsi nelayan terhadap PERMEN KP 2/2015 mengenai alat tangkap Dogol (Pukat Hela) dengan indikator pengetahuan larangan penggunaan alat tangkap menduduki kategori tinggi (skor 424), yang berarti sebagian besar nelayan sudah tahu tentang peraturan larangan tersebut. Tetapi indikator kesadaran menduduki kategori sedang (skor 327) yang berarti masyarakat nelayan sebagian belum sadar akan dampak dari penggunaan alat tangkap tersebut, demikian pula pada indikator minat (skor 264) menduduki kategori rendah yang berarti nelayan belum mau beralih menggunakan alat tangkap lain.

2. Sikap nelayan terhadap pelarangan penggunaan alat tangkap Dogol, dalam hal ini para nelayan tidak bersedia beralih kealat tangkap lainnya seperti Trammel net, Pancing rawai dan Gill nets, yang di sarankan oleh dinas kelautan sebagai pengganti alat tangkap Dogol. Hal ini karena para nelayan menganggap alat tangkap pengganti tersebut dianggap sebagai alat tangkap musiman kemudian hasil tangkapannya masih jauh lebih menguntungkan menggunakan alat tangkap dogol.

\section{SARAN}

1. Dalam menerbitkan sebuah regulasi, pemerintah diharapkan juga mampu memberi solusi terhadap permasalahan sosial ekonomi yang timbul dari pemberlakuan regulasi tersebut.

2. Pemerintah harus bekerja sama dengan aparat penegak hukum dan organisasi nelayan dalam hal 
menyiapkan langkah - langkah strategis, seperti konversi alat tangkap Dogol (Pukat Hela) ke alat tangkap yang ramah lingkungan.

3. Harus ada kajian lebih dalam guna mencari solusi untuk nelayan yang saat ini menggunakan alat tangkap Dogol (Pukat hela) mengenai alat alternatif yang paling memungkinkan digunakan masyarakat nelayan di Kelurahan Manggar Baru.

4. Nelayan berharap agar pemerintah mengevaluasi PERMEN KP 2/15 untuk memberikan keringanan bukan menghapus alat tangkap Dogol dengan cara melakukan standarisasi kapal yang digunakan oleh nelayan.

\section{DAFTAR PUSTAKA}

Kementerian Kelautan dan Perikanan Republik Indonesia Nomor 2/PERMEN-KP/2015 Tentang Larangan Penggunaan Alat Penangkapan Ikan Pukat Hela (Trawls) Dan Pikat Tarik (Seine Nets) Di Wilayah Pengelolaan Perikanan Negara Republik Indonesia. Aldaulah. uinsby. ac. id /index. Php / aldaulah /article / download/7/ pdf_1. (diakses tanggal 20 Desember 2016)

M. Subana dan Sudrajat. 2001. Dasardasar Penelitian Ilmiah. Bandung : CV. Pustaka Setia.

Pusat Penyuluhan dan Pemberdayaan Masyarakat Kelautan Dan Perikanan. Ayo penyuluh sosialisasikan permen $\mathrm{kp}$ no. 2 tahun
2015. http://www.-pusluh.kkp.go.id/ arsip/c/1810/?category id=17

(diakses tanggal 20 Desember 2016)

Pusat Penyuluhan dan Pemberdayaan Masyarakat Kelautan Dan Perikanan. Mengapa Pukat Hela (Trawls) dan Pukat Tarik (SeineNets) Dilarang Beroperasi di Perairan Kabupaten Langkat. http ://www http:// pusluh .kkp.go.id/ arsip/c/2184/?categoryid=1. (diakses tanggal 20 Desember 2016)

Republik Indonesia. 2004. Undang Undang Republik Indonesia Nomor 32 Tahun 2004 Tentang Pemerintahan Daerah. Lembaran Negara Republik Indonesia Tahun 2004.

Suratiyah, Ken. 2009. Ilmu Usahatani, Cetakan ke IV. Penebar Swadaya, Jakarta

Suparman, I. A. 1990. Statistik sosial.Rajawali pres, Jakarta 